Grażyna Cholewińskal, Ewa Siewaszewicz', Joanna Robak ${ }^{3}$, Elżbieta Dawid ${ }^{4}$, Jolanta Smykiewicz ${ }^{5}$, Wanda Skowron ${ }^{6}$

\title{
IMPACT OF A STRUCTURED MEDICAL STAFF EDUCATION PROGRAM ON THE EFFECT OF HIV TESTING IN FOUR MULTI-SPECIALIST HOSPITALS OF THE MAZOWIECKIE VOIVODESHIP AS A PART OF THE "STOP LATE PRESENTERS" PROJECT
}

\author{
WPEYW USTRUKTURYZOWANEGO PROGRAMU EDUKACJI \\ PERSONELU MEDYCZNEGO NA EFEKT TESTOWANIA W KIERUNKU HIV \\ W CZTERECH WIELOSPECJALISTYCZNYCH SZPITALACH WOJEWÓDZTWA \\ MAZOWIECKIEGO W RAMACH PROJEKTU „STOP LATE PRESENTERS”
}

${ }^{1}$ Hospital of Infectious Diseases in Warsaw

${ }^{2}$ GILEAD Sciences Poland

${ }^{3}$ Regional Hospital in Plock

${ }^{4}$ Jozef Psarski Mazovian Specialist Hospital in Ostroleka

${ }^{5}$ Tytus Chalubinski Specialist Hospital in Radom

${ }^{6}$ St. John Paul II Mazovian Regional Hospital in Siedlce

${ }^{1}$ Wojewódzki Szpital Zakaźny w Warszawie

${ }^{2}$ GILEAD Sciences Poland

${ }^{3}$ Wojewódzki Szpital Zespolony w Płocku

${ }^{4}$ Mazowiecki Szpital Specjalistyczny im. Józefa Psarskiego w Ostrołęce

${ }^{5}$ Radomski Szpital Specjalistyczny im. Tytusa Chałubińskiego w Radomiu

${ }^{6}$ Mazowiecki Szpital Wojewódzki im. Św. Jana Pawła II w Siedlcach

\begin{abstract}
In half of newly detected cases of HIV infection in Europe, the diagnosis is made late. This has significant impact on the effects of antiretroviral therapy, long-term consequences of the disease, mortality, and the risk of HIV transmission in the environment. As part of the large "STOP Late Presenters" project, the number of HIV tests was assessed in four multi-specialist hospitals in the Mazowieckie voivodeship, which generally carry out over 112,000 hospitalizations per year. First, under the structured research program, the training of medical personnel was carried out in these hospitals, and then the number of HIV tests ordered was evaluated 2 months and 4 months after the training. $459 \mathrm{HIV}$ tests were performed after the training in all hospitals, which is $2.44 \%$ of hospitalizations. It is interesting to note that after 4 months, the number of performed tests fell significantly. Staff training resulted in the number of tests higher by $5.8 \%$, compared to the same period of previous year. Four positive results were confirmed, which is $0.87 \%$ of all tests done. This is almost twice higher than in other European countries. Tests for HIV infection are most often ordered by doctors of infectious diseases, gynecologists and the staff of dialysis departments. We found that there is little interest in HIV testing among other specialists, despite reporting patients with clinical symptoms that suggest the likelihood of this infection. The improvement in HIV testing is of great importance for public health in our country and requires modification of diagnostic algorithms in hospital wards to reduce the number of late diagnoses of HIV / AIDS.
\end{abstract}

Key words: HIV, late diagnosis, testing, education 


\section{STRESZCZENIE}

Późne rozpoznania infekcji HIV dotyczą w Europie połowy nowo wykrywanych zakażeń. Ma to istotny wpływ na efekty leczenia antyretrowirusowego, odległe konsekwencje choroby, śmiertelność oraz trwające przez wiele lat ryzyko transmisji wirusa HIV w otoczeniu. W ramach ogólnopolskiego projektu „STOP Late Presenters" oceniono liczbę wykonywanych testów w kierunku HIV w czterech wielospecjalistycznych szpitalach w województwie mazowieckim, które łącznie realizują ponad 112000 hospitalizacji rocznie. W ramach ustrukturyzowanego programu badawczego przeprowadzono najpierw szkolenie personelu medycznego w tych szpitalach, a następnie sprawdzono liczbę zleconych testów HIV w 2 miesiące i 4 miesiące po szkoleniu. We wszystkich szpitalach wykonano odpowiednio 459 i 410 testów na obecność wirusa HIV po szkoleniu, co stanowi średnio $2,44 \% \mathrm{w}$ stosunku do liczby hospitalizacji. Zainteresowanie wykonywaniem badania istotnie zmalało po 4 miesiącach. Szkolenie personelu spowodowało wzrost liczby wykonanych testów o 5,8\% w stosunku do takiego samego okresu w roku poprzednim. Potwierdzono 4 wyniki dodatnie, co stanowi $0,87 \%$ wszystkich wykonanych testów i jest prawie dwukrotnie wyższym odsetkiem w porównaniu z innymi krajami Europy, które wykonywały podobny screening infekcji HIV. Badania w kierunku HIV najczęściej zlecają lekarze o specjalnościach: choroby zakaźne, specjaliści ginekologii oraz pracownicy oddziału dializ. Zwraca uwagę niewielkie zainteresowanie testowaniem HIV wśród pozostałych specjalistów, pomimo zgłaszania się pacjentów z objawami klinicznymi, które sugerują prawdopodobieństwo tej infekcji. Poprawa w zakresie testowania HIV ma duże znaczenie dla zdrowia publicznego w naszym kraju i wymaga modyfikacji algorytmów diagnostycznych w oddziałach szpitalnych, w celu zmniejszenia liczby późnych rozpoznań HIV/AIDS.

Slowa kluczowe: HIV, późna diagnoza, testowanie, edukacja

\section{INTRODUCTION}

In Europe, it is estimated that nearly $30 \%$ of people infected with human immunodeficiency virus (HIV) are not aware of the infection (1). Currently half of newly diagnosed patients have the CD4+ T cell count below $350 / \mu \mathrm{L}$ at the time of diagnosis, which significantly impacts their worse prognosis, higher mortality rate, higher number of complications, worse response to antiretroviral therapy, but also higher risk of transmission to other people and, generally, higher costs of medical care $(2,3)$. Late diagnoses of HIV infection (so-called late presenters) are made too often and concern a large population of infected patients, both in Poland (around 50\%) and in Europe $(2,4)$. In face of such a high number of people unaware of their HIV status, it is essential for public health to improve HIV infection detection at an early stage of the disease. European Centre for Diseases Prevention and Control (ECDC) recommends routine tests in hospitals, where $\mathrm{HIV}(+)$ patients constitute at least $1 \%$ of all patients (2). However, routine HIV tests in such hospitals are seldomly performed, which may result from the fact that ECDC did not establish precisely, who should order routine tests and in which clinical conditions. In the document "Public health guidance on HIV, hepatitis B and C testing in the EU/ EEA - An integrated approach" (5), ECDC describes the groups and populations that should be tested for $\mathrm{HIV}$; it also describes strategies for management in healthcare institutions, but does not list clinical indications for testing in individual areas of the

\section{WSTĘP}

Szacuje się, że w Europie blisko 30\% osób zakażonych ludzkim wirusem niedoboru odporności (HIV) nie ma świadomości infekcji (1). Aktualnie połowa nowo zdiagnozowanych osób w chwili rozpoznania ma liczbę limfocytów T CD4 mniejszą niż 350/ $\mu \mathrm{L}$, co ma istotny wpływ na gorsze rokowanie, większą śmiertelność, większą liczbę powikłań zdrowotnych, gorszą odpowiedź na terapię przeciwwirusową, ale także na zwiększone ryzyko transmisji zakażenia na inne osoby i ogólnie - na wyższe koszty opieki medycznej $(2,3)$. Późne rozpoznania infekcji HIV (ang. late presenters) są zbyt częste i dotyczą dużej populacji zakażonych zarówno w Polsce (około 50\%), jak i w całej Europie $(2,4)$. Przy tak dużej liczbie osób nieświadomych swojego statusu HIV, kluczowe znaczenie dla zdrowia publicznego mają wysiłki poprawiające wykrywanie zakażenia HIV we wczesnym stadium choroby. European Centre for Diseases Prevention and Control (ECDC) zaleca rutynowe testy w szpitalach, w których pacjenci HIV $(+)$ stanowią co najmniej $1 \%$ całkowitej populacji pacjentów w szpitalu (2). Jednak rutynowe testy HIV w takich szpitalach są rzadko przeprowadzane, co może wynikać $\mathrm{z}$ faktu, że ECDC nie określiło dokładnie, kto powinien wykonywać rutynowe testy i $\mathrm{w}$ jakich okolicznościach klinicznych. W dokumencie ECDC zatytułowanym „Public health guidance on HIV, hepatitis $B$ and $C$ testing in the EU/EEA - An integrated approach" (5), opisano grupy i populacje, które powinny mieć wykonany test w kierunku HIV, określono też strategie postępowania dla jednostek ochrony zdrowia, ale nie wymieniono tam 
healthcare system. Such recommendations may be found either in national guidelines or in the guidelines of individual scientific associations (2).

Moreover, American reports confirm that testing for diseases whose prevalence is at least $0.1 \%$ is costeffective (6).

Based on many surveys made on medical personnel, we found that the awareness of HIV infection and AIDS, including infection prevalence and transmission routes and diagnostic and therapeutic possibilities is insufficient for making rational diagnostic decisions. In Poland, HIV testing is done mainly in 30 non-public institutions, so-called Consultation and Diagnosis Points (CDP), which perform around 30 thousand tests a year. Each year, data from CDPs are reported to the National Center for AIDS. The number of all the tests ordered in public healthcare institutions is not announced, because the obligation to report is only binding in the case of positive results. Data on positive results is reported to respective Sanitary and Epidemiological Stations and then unified into epidemiological analyses presented by the National Institute of Public Health - National Institute of Hygiene.

In our country, in many hospitals it is obligatory to inform the patient with high probability of HIV infection that he will be tested. In some countries it is decided that performance of the HIV test in a medical setting should depend on the co-existence of other diseases and clinical conditions pointing to the possibility of HIV infection or AIDS (7). As the patient with opportunistic disease suggesting AIDS may be hospitalized in different hospital wards, many countries developed national guidelines specifying characteristics of such diseases and proposing a sequence of steps that should be taken in order to perform diagnosing tests.

Poland is among many countries that joined the project "STOP Late Presenters", aiming at raising awareness on early HIV testing, in order to use the chance of early diagnosis and treatment of the infection. Testing for HIV infection is an important problem in Poland. In our country, we perform less than $1 / 10$ of the number of tests performed in Western European countries. There are various reasons for this situation. One of them is insufficient awareness of medical staff, especially doctors - specialists of different kinds, who should take HIV into consideration while diagnosing other conditions, but they often don't. At the moment, in Polish hospitals it is most important to educate the personnel in different segments of the healthcare system that a patient with HIV/AIDS may be hospitalized in every type of ward and may be consulted in every outpatient center. przesłanek klinicznych do testowania w poszczególnych dziedzinach ochrony zdrowia. Tego typu zalecenia mogą się znajdować albo w niektórych narodowych przewodnikach, albo jako wytyczne poszczególnych towarzystw naukowych (2).

Ponadto doniesienia amerykańskie potwierdzają, że wykonywanie testów diagnozujących w przypadku różnych chorób, których częstość wynosi co najmniej $0,1 \%$, jest efektywne kosztowo (6). Na podstawie wielu badań ankietowych personelu medycznego, można stwierdzić, że wiedza na temat infekcji HIV i choroby AIDS, tj. rozpowszechnienia zakażenia, dróg transmisji oraz możliwości diagnostyczno-terapeutycznych jest niewystarczająca do podejmowania racjonalnych decyzji diagnostycznych. W Polsce testowanie w kierunku HIV odbywa się przede wszystkim w 30 jednostkach niepublicznych, tzw. Punktach Konsultacyjno - Diagnostycznych (PKD), które rocznie wykonują około 30 tys. testów. Dane z PKD są co roku raportowane do Krajowego Centrum ds. AIDS. Liczba wszystkich zlecanych testów w publicznych podmiotach ochrony zdrowia nie jest znana, ponieważ obowiązek raportowania dotyczy tylko wyników dodatnich. Dane o wynikach dodatnich są raportowane do odpowiednich stacji sanitarno-epidemiologicznych, a z nich powstają analizy epidemiologiczne prezentowane przez NIZP-PZH.

$\mathrm{W}$ wielu szpitalach w naszym kraju istnieje potrzeba informowania o testowaniu HIV w odniesieniu do pacjentów z dużym prawdopodobieństwem tego zakażenia. W niektórych krajach europejskich przyjęto stanowisko, aby wykonywanie testów na obecność wirusa HIV w placówkach medycznych było wyznaczone przez występowanie chorób i stanów klinicznych, wskazujących na możliwość infekcji HIV lub choroby AIDS (7). Uznając, że pacjent z chorobą oportunistyczną wskazującą na AIDS może być hospitalizowany w różnych oddziałach szpitalnych, w wielu krajach stworzono narodowe przewodniki, które podają charakterystykę takich chorób i wskazują kolejne kroki w wykonywaniu testów diagnozujących.

Polska znalazła się wśród wielu krajów, które włączyły się do projektu „STOP Late Presenters”, mając na uwadze uświadomienie potrzeby wczesnego testowania HIV w celu wykorzystania szansy wczesnego rozpoznania i leczenia infekcji. Testowanie w kierunku infekcji HIV jest w Polsce istotnym problemem. W naszym kraju wykonuje się mniej niż 1/10 liczby testów HIV w porównaniu do krajów Europy Zachodniej. Przyczyny tego są zróżnicowane. Jedną z nich jest niedostateczna wiedza pracowników medycznych, zwłaszcza lekarzy - specjalistów różnych dziedzin, którzy w diagnostyce określonych stanów klinicznych powinni uwzględniać test na HIV, ale nie zawsze to robią. W polskich szpitalach najważniejsze staje się obecnie uświadomienie personelowi różnorodnych 
Presentation of the need to test for HIV with simple screening tests is the main part of a large, nationwide project „STOP Late Presenters”. Educational project run within a clinical series of lectures, was addressed to doctors of different specialties and other staff of the healthcare system. Medical staff were shown a broad spectrum of pathological symptoms, that may result from undiagnosed HIV infection. Then, on two time intervals, we evaluated whether the number of ordered HIV tests increased after the lecture in individual hospital wards and outpatient centers, in order to determine whether the materials shown on presentations and leaflets increased the number of performed tests in individual hospital departments. The study was done in four large, multi-specialist hospitals in the Mazowieckie voivodeship, and the research hypothesis assumed that a structured training concerning this topic increased the number of performed HIV tests.

\section{MATERIALS AND METHODS}

Four hospitals in the Mazowieckie voivodeship, belonging to the healthcare network system, were appointed for the analysis of the effects connected with the structured program of HIV/AIDS education among medical staff. Those were: Regional Hospital in Plock, Józef Psarski Mazovian Specialist Hospital in Ostroleka, Tytus Chalubinski Specialist Hospital in Radom and St. John Paul II Mazovian Regional Hospital in Siedlce. Study coordinators contacted the heads of these hospitals requesting them to send information from laboratories, concerning the number of performed tests, after two months and four months after the training. Structured program included three elements:

1. training in the form of presentation prepared by an HIV/AIDS expert, that was shown at the regional clinical lecture in every hospital,

2. distribution of information materials and leaflets listing conditions and diseases suggesting probability of HIV infection in patients in hospital wards and outpatient centers with different specialists,

3. survey with analysis of data on the number of performed tests, sent by the representatives of laboratories of all four hospitals.

Both visual presentation and information materials contained characteristics of patients infected with HIV, showing broad spectrum of symptoms requiring detailed diagnostics, including the test for HIV.

Doctors employed in the hospitals and hospital clinics - specialists in different fields - were invited to participate voluntarily in the lecture. On top of that, a small group of other hospital employees consisted segmentów opieki zdrowotnej, że pacjent z HIV/AIDS może trafić do każdego oddziału szpitalnego i każdego gabinetu lekarskiego.

Przedstawienie potrzeby testowania w kierunku HIV za pomocą prostych testów przesiewowych jest głównym motywem dużego, ogólnopolskiego projektu w ramach „STOP Late Presenters”. Projekt edukacyjny w ramach spotkań klinicznych, adresowany był do lekarzy różnych specjalności oraz innych pracowników opieki zdrowotnej. Pokazano w nim szerokie spektrum symptomów chorobowych, które mogą wynikać z nierozpoznanego dotąd zakażenia HIV. Następnie, w dwóch interwałach czasu oceniano, czy po szkoleniu zwiększyła się liczba zlecanych testów HIV w poszczególnych oddziałach szpitalnych i poradniach oraz na ile treści pokazane w prezentacjach i ulotkach wpłynęły na zwiększenie liczby wykonanych testów w poszczególnych jednostkach szpitala. Badanie wykonano w czterech dużych, wielospecjalistycznych szpitalach województwa mazowieckiego, a hipoteza badawcza zakładała, że szkolenie ustrukturyzowane w przedstawionej wyżej kwestii, wpłynęło na zwiększenie liczby wykonanych testów HIV.

\section{MATERIAŁ I METODY}

Do analizy efektów ustrukturyzowanego programu edukacji pracowników medycznych w tematyce HIV/ AIDS wyznaczono cztery szpitale sieciowe województwa mazowieckiego. Były to: Wojewódzki Szpital Zespolony w Płocku, Mazowiecki Szpital Specjalistyczny im. Józefa Psarskiego w Ostrołęce, Radomski Szpital Specjalistyczny im. Tytusa Chałubińskiego w Radomiu i Mazowiecki Szpital Wojewódzki im. Św. Jana Pawła II w Siedlcach. Realizatorzy projektu zwrócili się do dyrektorów w/w szpitali z prośbą o udostępnienie danych z laboratoriów o liczbie wykonanych testów - w dwa miesiące oraz w cztery miesiące po szkoleniu. Ustrukturyzowany program zawierał trzy elementy:

1. szkolenie $\mathrm{w}$ formie prezentacji przygotowanej przez eksperta HIV/AIDS, którą przedstawiono na regionalnym spotkaniu klinicznym w każdym ze szpitali,

2. rozpowszechnienie materiałów informacyjnych i ulotek określających stany i choroby sugerujące prawdopodobieństwo infekcji HIV u pacjentów w oddziałach szpitalnych i gabinetach różnorodnych specjalistów,

3. kwestionariusz z opracowaniem danych o liczbie wykonanych testów, przesłany przez przedstawicieli laboratoriów wszystkich czterech szpitali.

Zarówno prezentacja wizualna, jak i materiały informacyjne zawierały charakterystykę chorych zakażonych HIV, którzy mają szerokie spektrum objawów chorobowych wymagających szczegółowej diagnostyki, w tym testu w kierunku HIV. 
of nurses, laboratory diagnosticians and white collar employees. In total, 170 medical employees were trained, mostly doctors, because the training was done in the course of hospital clinical lectures addressed to doctors. Moreover, the organizers of the study decided that doctors are responsible for ordering diagnostic tests.

In the second stage of the study, a contact person in laboratories filled out a survey developed by the coordinators of nationwide project "STOP Late Presenters". The survey contained questions concerning the general number of hospitalized patients, the number of ordered HIV tests at 2 and 4 months after the training and at the same time last year, characteristics of individual departments of the hospital ordering tests, characteristics of specialist doctors, that ordered the test for HIV. Finally, the survey included a descriptive characteristic pertaining to barriers and obstacles in HIV testing at the laboratory level. Among collected data there were no pieces of information identifying patients, so the study fulfilled legal regulations and did not require consent of ethical committee. The study was performed between March and October 2019.

Results of the analysis were presented in the form of raw data and percentages - because of small numbers in data sets and no control group in the study.

\section{RESULTS}

We analyzed data presented in the HIV Testing Evaluation Questionnaire, derived from diagnostic laboratories of four multi-specialist hospitals in the Mazowieckie voivodeship (Plock, Ostroleka, Radom, Siedlce). In 2018, in each of the hospitals, the number of hospitalized patients was from about 25000 to 35000 (Table 1).
Uczestnikami dobrowolnego szkolenia byli lekarze zatrudnieni w szpitalach i poradniach przyszpitalnych specjaliści różnych dziedzin, a także nieliczna grupa pielęgniarek, diagnostów laboratoryjnych i pracowników administracji. Ogółem przeszkolono 170 pracowników medycznych - w większości byli to lekarze, ponieważ szkolenie odbywało się w ramach szpitalnych spotkań klinicznych, które są adresowane głównie do środowiska lekarzy. Ponadto organizatorzy badania uznali, że to właśnie lekarze są odpowiedzialni za zlecanie badań diagnostycznych.

W drugim etapie badania, przedstawiciele laboratoriów wypełniali kwestionariusz opracowany przez realizatorów ogólnopolskiego projektu „STOP Late Presenters". Kwestionariusz zawierał pytania dotyczące ogólnej liczby hospitalizowanych w szpitalach, liczby zlecanych testów HIV w okresie 2 i 4 miesięcy po szkoleniu oraz $\mathrm{w}$ analogicznym okresie roku poprzedniego, specyfiki jednostek szpitala zlecających testy, charakterystyki lekarzy specjalistów, którzy kierowali na badanie w kierunku HIV. W końcowej części kwestionariusz uwzględniał charakterystykę opisową odnoszącą się do barier i trudności w testowaniu HIV na poziomie laboratoryjnym. Wśród zgromadzonych danych nie było informacji identyfikujących pacjenta, więc badanie spełniało warunki RODO i nie wymagało zgody komisji etycznej. Badanie trwało od marca do października 2019 roku.

Wyniki analizy przedstawiono $\mathrm{w}$ formie liczb surowych i odsetków - ze względu na niewielkie liczby w zbiorach oraz na brak założonej w badaniu grupy odniesienia.

\section{WYNIKI}

Analizowano dane zawarte w Kwestionariuszach Oceny Testowania w kierunku Infekcji HIV, pochodzące z laboratoriów diagnostycznych czterech szpitali wielospecjalistycznych województwa mazowieckiego (Płock, Ostrołęka, Radom, Siedlce). W każdym ze szpitali liczba hospitalizowanych w 2018 roku wynosiła od około 25000 do 35000 (Tab.I).

Table I. Total number of hospitalizations in 2018

Tabela I. Ogólna liczba hospitalizacji w 2018 roku

\begin{tabular}{|c|c|c|}
\hline & HEALTHCARE INSTITUTION & $\begin{array}{c}\text { TOTAL NUMBER OF } \\
\text { HOSPITALIZATIONS IN 2018 }\end{array}$ \\
\hline No. 1 & Regional Hospital in Plock & 35094 \\
\hline No. 2 & Józef Psarski Mazovian Specialist Hospital in Ostroleka & 25702 \\
\hline No. 3 & Tytus Chalubinski Specialist Hospital in Radom & 27444 \\
\hline No. 4 & St. John Paul II Mazovian Regional Hospital in Siedlce & 24688 \\
\hline & Total & $\mathbf{1 1 2 9 2 8}$ \\
\hline
\end{tabular}


We analyzed the number of ordered HIV tests at 2 and 4 months after the training and compared the results with the number of tests performed during the same time, previous year (2018). At the analyzed time points, two months after the training in 2019, we noticed the rise of the number of HIV tests ordered by $5.8 \%$, compared to the same period of the previous year. In all four healthcare institutions of the Mazowieckie voivodeship, during the time of the study, 4 positive test results were confirmed (screening test and western-blot). All positive results of HIV test were found only in the pool collected after 2 months and this fact may be just a coincidence. Those 4 positive cases constitute $0.87 \%$ of all ordered tests, i.e. 459 assays. In the samples ordered after 4 months post-training, no positive result could be confirmed.

During the time up to 2 months after the training on HIV infection, altogether 459 tests were performed in four healthcare institutions, which is around $2.44 \%$ in relation to the number of hospitalizations declared by the hospital, adjusted as the average standard of hospitalization during 2 months, while during the next 2-4 months the number of performed HIV tests decreased and reached 410 , which is about $2.18 \%$. In 2019, the number of ordered HIV tests during the period up to 2 months after the training was higher by 25 tests, compared to the same time in 2018 . Meanwhile, during the next 2-4 months after the training, in 2019 it was lower by 34 tests than during the same time in 2018 (Table II).
Oceniano liczbę zleconych testów HIV w okresie 2 miesięcy i 4 miesięcy po szkoleniu, a wyniki porównano z liczbą testów wykonanych w tym samym czasie w roku poprzednim (2018). W analizowanych okresach, w punkcie ocenianym w dwa miesiące po szkoleniu w 2019 roku, stwierdzono wzrost liczby skierowań na test HIV o 5,8\% w porównaniu do analogicznego okresu roku poprzedniego. We wszystkich czterech podmiotach leczniczych województwa mazowieckiego w czasie trwania badania potwierdzono 4 dodatnie wyniki testu (test przesiewowy i western-blot). Wszystkie dodatnie wyniki testu HIV uzyskano tylko w próbie po 2 miesiącach i to zdarzenie można uznać za przypadkowe. Stanowi to $0,87 \%$ zleconych w tym czasie badań, tj. 459 testów. W próbkach zleconych po 4 mies. od szkolenia, nie potwierdzono żadnego wyniku dodatniego.

W okresie do 2 miesięcy po szkoleniu nt. infekcji HIV, w czterech podmiotach leczniczych wykonano łącznie 459 testów HIV, co stanowi ok. 2,4\% w stosunku do zadeklarowanej przez szpital liczby hospitalizacji przeliczonej na średni standard hospitalizacji w ciągu 2 miesięcy, natomiast w okresie kolejnych 2 - 4 miesięcy liczba przeprowadzonych badań HIV zmniejszyła się i wynosiła 410 testów, co stanowi ok. 2,2\%.

W roku 2019 liczba skierowań na test HIV w okresie do 2 miesięcy po szkoleniu była wyższa w porównaniu do analogicznego okresu w roku 2018 o 25 testów. Natomiast w okresie kolejnych 2-4 miesięcy po szkoleniu, była w 2019 niższa w porównaniu do analogicznego okresu w roku 2018 o 34 testy (Tab. II).

Table II. Number of HIV tests carried out 2 and 4 months after the training in 2019, compared to the same period in 2018 Tabela II. Liczba wykonywanych testów HIV 2 oraz 4 mies. po szkoleniu w 2019 roku w porównaniu z analogicznym okresem w 2018 roku

\begin{tabular}{|c|c|c|c|c|}
\hline \multicolumn{6}{|c|}{ NUMBER OF PERFORMED HIV TESTS } \\
\hline INSTITUTION & $\begin{array}{c}2019, \\
\text { MONTHS AFTER } \\
\text { TRAINING }\end{array}$ & $\begin{array}{c}2018, \\
\text { DURING THE } \\
\text { SAME PERIOD }\end{array}$ & $\begin{array}{c}\text { MONT, } \\
\text { MONTS AFTER } \\
\text { TRAINING }\end{array}$ & $\begin{array}{c}\text { DURING THE } \\
\text { SAME PERIOD }\end{array}$ \\
\hline No. 1 & 132 & 113 & 118 & 116 \\
\hline No. 2 & 148 & 136 & 138 & 146 \\
\hline No. 3 & 130 & 142 & 131 & 124 \\
\hline No.4 & 49 & 43 & 23 & 58 \\
\hline Total & $\mathbf{4 5 9}$ & $\mathbf{4 3 4}$ & $\mathbf{4 1 0}$ & $\mathbf{4 4 4}$ \\
\hline
\end{tabular}

The difference between the number of performed tests during comparable periods of 2018 and 2019 two months after the training was $5.8 \%$, which proves that professional training and reminding about HIV testing does matter in the practice of multi-specialist hospitals.
Różnica pomiędzy liczbą wykonanych testów w porównywalnych okresach w 2018 i 2019 w dwa miesiące po szkoleniu wynosiła $5,8 \%$, co dowodzi, że specjalistyczna edukacja i przypominanie o testowaniu HIV ma znaczenie w praktyce szpitali wielospecjalistycznych. 
While analyzing data for 2018 and 2019, we noticed the increase of the number of HIV tests performed in three out of four hospitals, in total, from 434 tests in 2018 to 459 in 2019 - during a calendar period corresponding to the analysis after 2 months post training, as well as decrease of the total number of tests in 2019 (410 tests) in respect to 2018 (444 tests), in the analysis corresponding to 2-4 months after the training (Fig. 1).

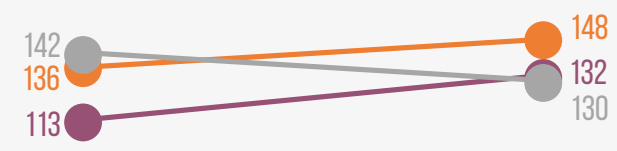

2018

corresponding period

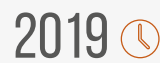

2 MONTHS after the training
434 тоTLL 459 ToTAL
Analizując dane dla 2018 i dla 2019 roku można zauważyć wzrost liczby wykonanych testów HIV w trzech spośród czterech szpitali. Ogółem odnotowano wzrost z 434 testów w roku 2018 do 459 w 2019 r. w okresie kalendarzowym odpowiadającym analizie do 2 mies. po szkoleniu oraz zmniejszenie ogólnej liczny testów w 2019 (410 testów) w stosunku do 2018 roku (444 testy) w analizie odpowiadającej kalendarzowym odpowiednikom 2-4 mies. po szkoleniu (Ryc.1).

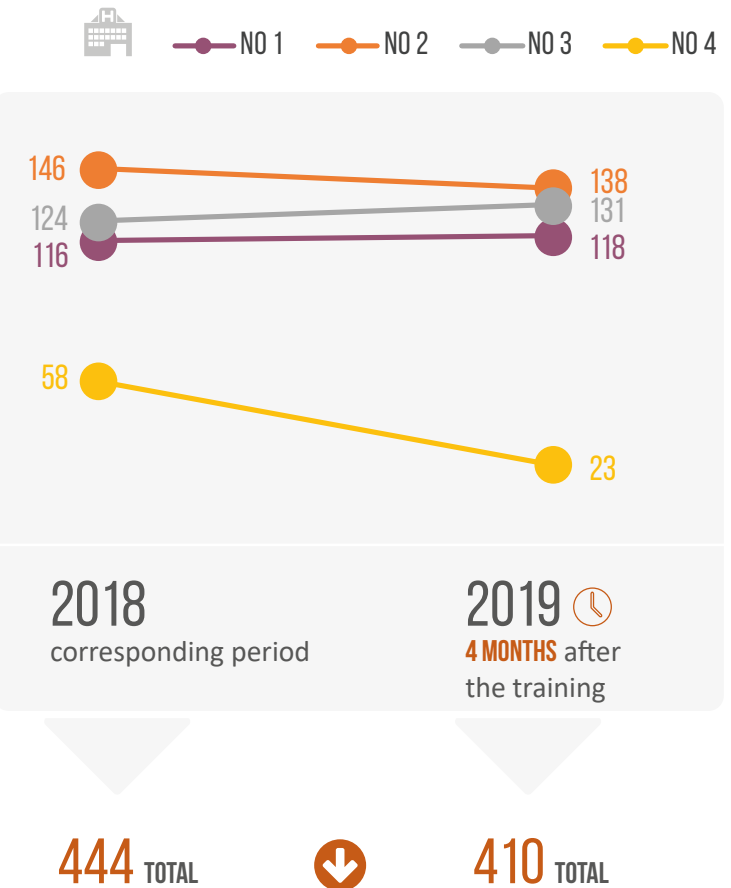

Fig.1. Number of HIV tests performed in 2019, compared to the same period in 2018

Ryc.1. Liczba wykonanych testów HIV w 2019 w porównaniu z 2018 rokiem - w analogicznych okresach roku

When we evaluated places where HIV tests were ordered, e.g. hospital wards or outpatient centers we noticed that after the training more than half of all HIV tests was performed among patients treated in hospital wards, in outpatient ob-gyn centers and infectious disease centers (Fig. 2 and Fig. 3).

As far as hospital wards are concerned, the following words ordered HIV testing: cardiology ward - in $6 \%$ of hospitalized patients, nephrology and dialysis $-18 \%$, neurology $-3 \%$, internal diseases $4 \%$, intensive care $-2 \%$. Analysis of the number of test orders sent from outpatient centers shows that in $24 \%$ cases they came from infectious disease center, in $44 \%$ cases from ob-gyn center and in $11 \%$ from hepatology center. Very small number of HIV tests, only $6 \%$, came from all other specialist center. We want to stress a significant increase of the number of orders coming from labor medicine center, especially in one of the healthcare institutions. We observed increase from the level of 18 tests during the first 2 months after the training to 40 tests within 2-4 months
W analizie określającej miejsce generowania skierowań na badanie HIV, tj. oddziały szpitalne lub poradnie, stwierdzono, że po szkoleniu ponad połowa wszystkich testów HIV przeprowadzana była wśród pacjentów leczonych w zarówno oddziałach jak i w poradniach ginekologiczno-położniczych oraz chorób zakaźnych (Ryc.2 i Ryc.3).

Oddziały szpitalne realizowały testowanie HIV odpowiednio: oddziały kardiologiczne u $6 \%$ hospitalizowanych, nefrologiczne z ośrodkiem dializ u $18 \%$, neurologiczne u 3\% chorych, oddziały chorób wewnętrznych u $4 \%$ i intensywna terapia u $2 \%$.

Analiza liczby skierowań na test HIV wygenerowanych z poradni pokazuje, że pochodziły one w $24 \%$ z poradni chorób zakaźnych i w $44 \%$ z poradni ginekologiczno-położniczych, a w $11 \%$ z poradni hepatologicznej. Bardzo mało, zaledwie $6 \%$ testów HIV pochodziło ze wszystkich pozostałych poradni specjalistycznych. Należy zwrócić uwagę na znaczny wzrost liczby skierowań pochodzących z Poradni Medycyny Pracy, zwłaszcza w jednym z podmiotów leczniczych. Z po- 


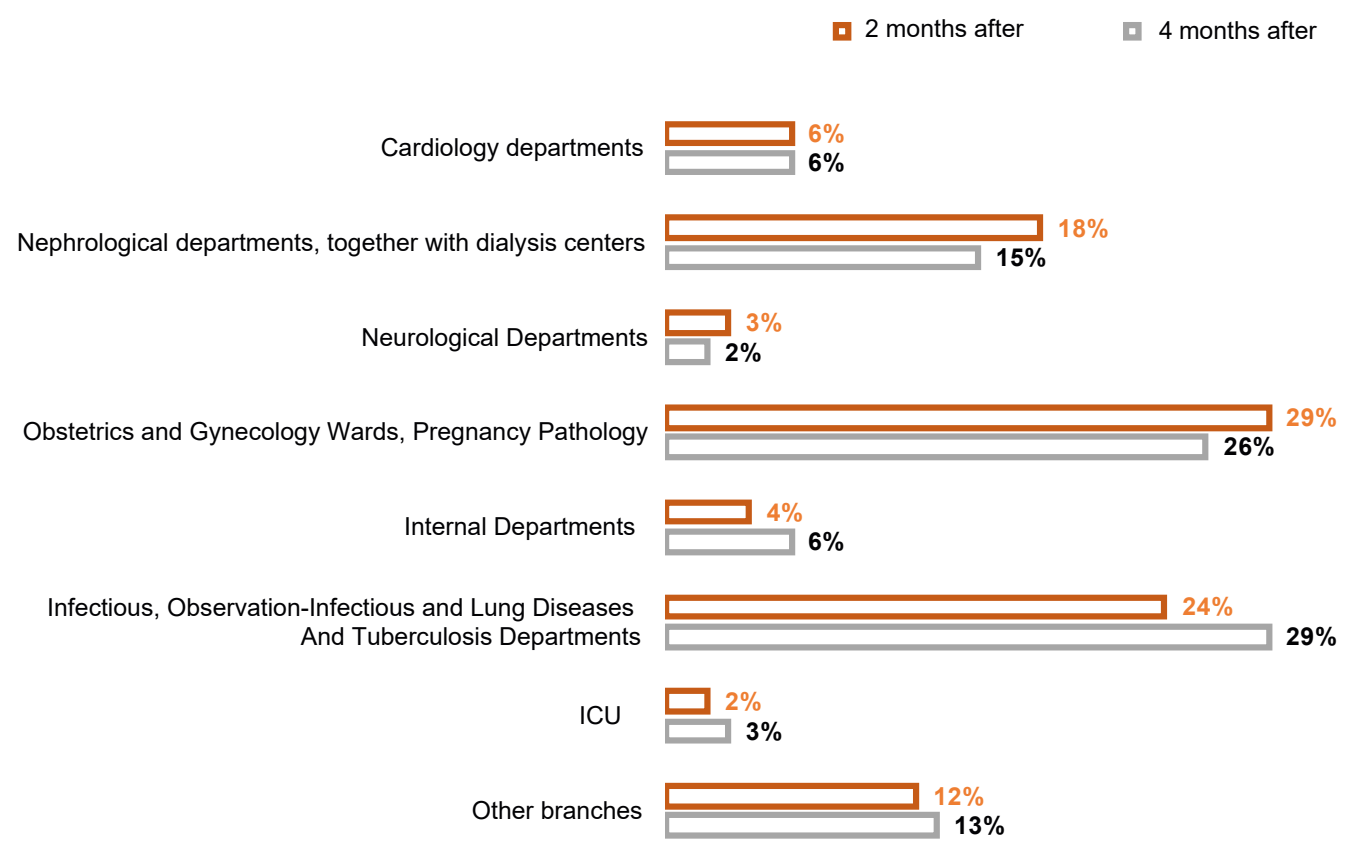

Fig 2. Number of HIV test referrals from hospital wards 2 and 4 month after the training (\%)

Ryc.2. Liczba skierowań na test HIV wystawionych przez oddziały szpitalne 2 i 4 miesiące po szkoleniu (\%)

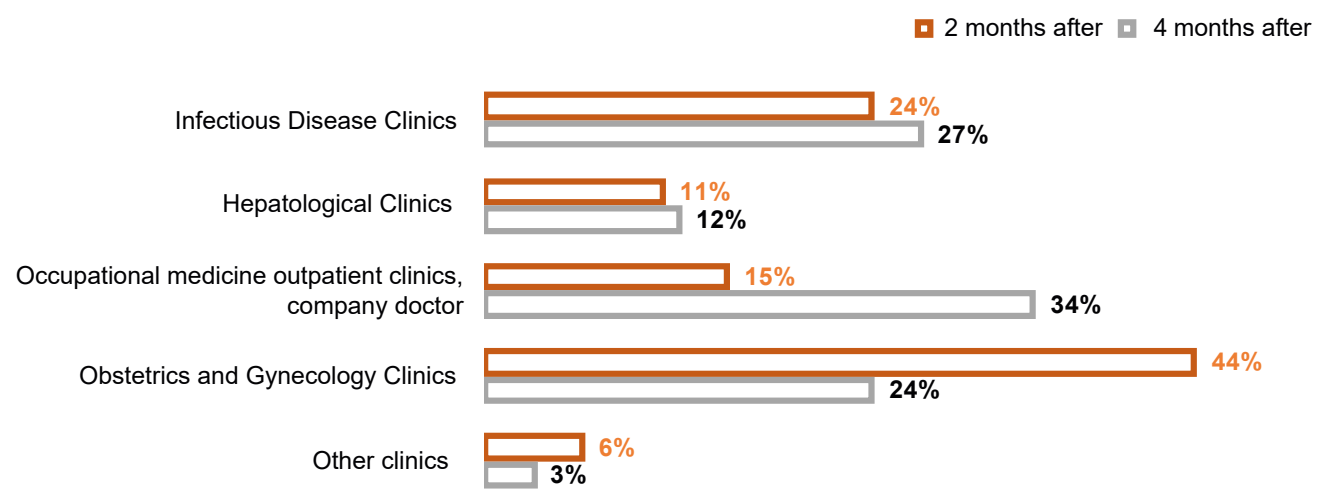

Fig.3. Number of HIV test referrals from outpatients centers 2 and 4 month after the training (\%)

Ryc.3. Liczba skierowań na test HIV wystawionych przez poradnie 2 i 4 miesiące po szkoleniu (\%)

after the training. We also demonstrated a significant fall of the number of tests ordered by ob-gyn center, from $44 \%$ to $24 \%$ (Fig. 3 ).

We also aimed at analyzing, which specialists order the highest and lowest proportion of HIV tests (Fig. 4.). Tests were mainly ordered by the specialists in infectious diseases, gynecology and internal medicine - nephrology department, probably with dialysis therapy. We noted a very small number of orders from specialists in neurology and cardiology, even if in the spectrum of HIV/AIDS there are many clinical symptoms from nervous and cardiovascular systems, which may suggest this infection. During educational lectures, doctors without specialty and residents were very interested in the topic of HIV testing, but their contribution in test ordering is very low, only $7-8 \%$. Also nurses and other medical personnel participated ziomu 18 badań w okresie pierwszych 2 miesięcy po szkoleniu odnotowano wzrost do 40 testów w okresie 2-4 miesiące po szkoleniu. Jednocześnie nastąpił znaczny spadek liczby skierowań w poradniach ginekologiczno-położniczych z 44\% do 24\% (Ryc. 3.).

Przedmiotem analizy badawczej było także wskazanie lekarzy określonych specjalności, którzy najczęściej i najrzadziej zlecają badanie w kierunku infekcji HIV (Ryc. 4.). Na test kierowali pacjentów głównie lekarze specjalności chorób zakaźnych, ginekologii oraz chorób wewnętrznych - sekcja nefrologii, prawdopodobnie z pododdziałem dializoterapii. Zwraca uwagę bardzo mała liczba skierowań pochodzących od lekarzy specjalistów neurologii i kardiologii, chociaż w symptomatologii HIV/AIDS istnieje wiele objawów klinicznych ze strony układu nerwowego i sercowo-naczyniowego, które mogą sugerować to zakażenie. Podczas spotkań 
in the trainings, but their contribution to the process of early HIV infection detection is minimal and certainly this group of professional requires further information and training.

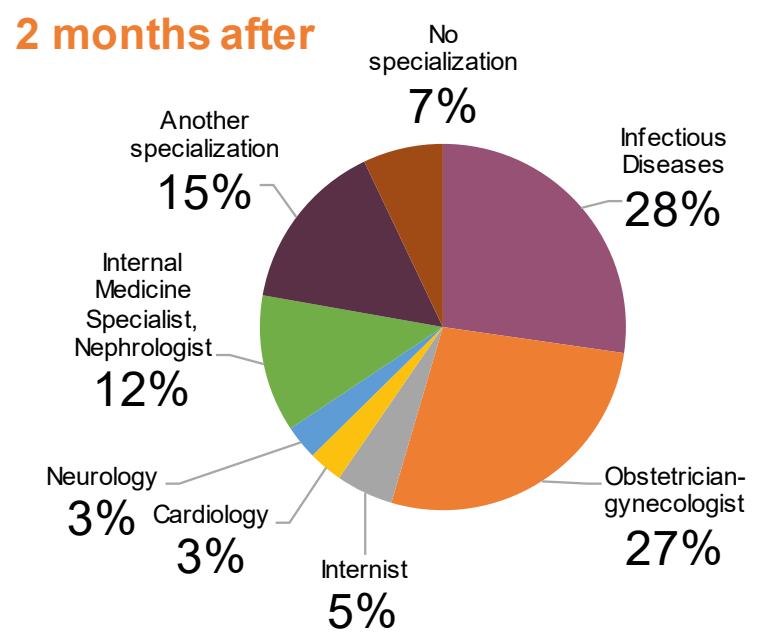

edukacyjnych duże zainteresowanie testowaniem HIV wykazywali lekarze bez specjalizacji i lekarze rezydenci, jednak ich udział w kierowaniu na badania jest bardzo mały, zaledwie 7-8\%. W szkoleniach uczestniczyły też pielęgniarki i inni pracownicy medyczni, ale ich udział w procesie wczesnego wykrywania zakażenia HIV jest minimalny i na pewno ta grupa zawodowa wymaga dalszej pracy informacyjno-szkoleniowej.

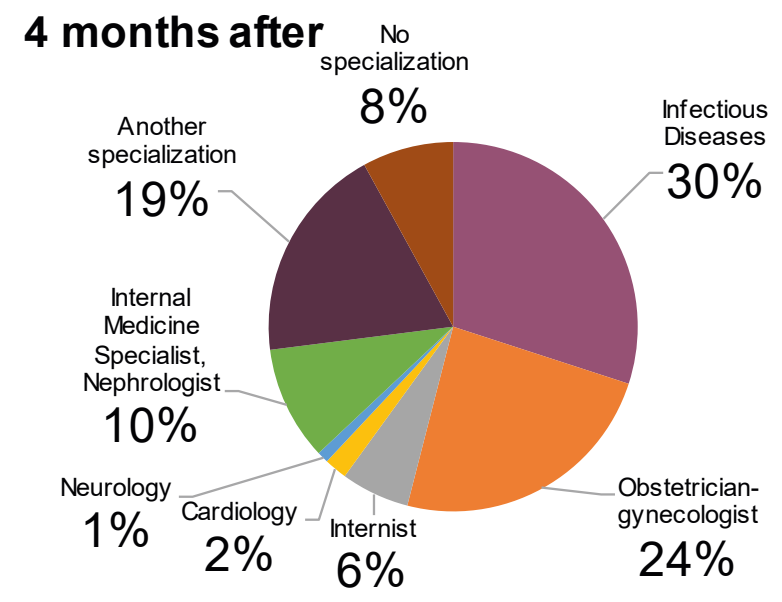

Fig.4. Number of HIV test referrals ordered by doctors of a specific specialization (\%)

Ryc.4. Liczba skierowań na test HIV wystawionych przez lekarzy określonej specjalizacji (\%)

\section{DISCUSSION}

The study planned within the framework of the project „STOP Late Presenters" showed higher interest of different specialists in the performance of HIV tests in patients, whose clinical symptoms pointed to probability of ongoing infection or AIDS. After the training, 5.8\% more tests were ordered. Women were tested more often, which is probably connected with prenatal care over pregnant woman.

A study with similar assumptions was performed by Spanish investigators in the framework of DRIVE project (8). Just like in Poland, they found that the guidelines concerning HIV testing are poorly followed in Spanish hospitals and do not cover most clinical cases that would suggest chronic HIV infection. The project comprised three elements - training of nurses and doctors facilitating the understanding of HIV/AIDS screening algorithm, survey for patients containing validated questions on events connected with high risk of HIV infection, and the third element, that including proposing and performing a screening test among patients. Education comprised presentation in the form of slides, a short abstract with the description of the project, consultation of an educator, brochure and leaflet, images with the instruction how to perform a rapid HIV test. The

\section{DYSKUSJA}

Zaplanowane badanie w ramach projektu „STOP Late Presenters" wykazało zwiększone zainteresowanie różnych specjalistów wykonywaniem testów HIV u pacjentów, których objawy kliniczne wskazywały na prawdopodobieństwo trwającej infekcji HIV lub choroby AIDS. Po szkoleniu zlecono o 5,8 \% więcej testów. Częściej testowane były kobiety, co jest związane prawdopodobnie z opieką przedporodową nad kobietą w ciąży.

Badanie o podobnym założeniu wykonali badacze hiszpańscy w ramach projektu DRIVE (8). Podobnie jak w Polsce, stwierdzali oni, że wytyczne dotyczące testowania HIV w hiszpańskich szpitalach są słabo wdrażane i nie pokrywają większości przypadków klinicznych, które sugerowałyby przewlekłą infekcję HIV. Projekt zawierał trzy elementy - trening pielęgniarek i lekarzy ułatwiający zrozumienie przeprowadzania screeningu HIV/AIDS, kwestionariusz dla pacjentów zawierający zwalidowane pytania o sytuacje wysokiego ryzyka HIV oraz trzeci element, który polegał na zaproponowaniu i wykonaniu testu przesiewowego wśród pacjentów. Edukacja obejmowała prezentacje $\mathrm{w}$ formie slajdów, krótkie streszczenie z opisem projektu, konsultacje edukatora, broszury i ulotki, obrazki z instrukcją wykonania rapid-testu HIV. Do programu włączono 5329 pacjen- 
program included 5329 patients aged 18-60, from several primary care centers and from hospitals in Madrid, among which $51.2 \%$ declared in the survey at least one response that confirmed the risk of HIV infection. The project lasted the whole year 2014 . $22(0.4 \%)$ new infections were identified, but $18 \%$ of people in whom positive result was confirmed were unaware of infection. As many as $40.9 \%$ of newly detected cases fulfilled he criteria of being late presenters. Indices determining the ordering of HIV test were calculated to be $29.6 / 100$ thousand patients in DRIVE study, while in routine practice not connected with the project, tests are only performed in 3.1 cases per 100 thousand. This confirms benefit of a structured educational program for medical staff. The number of ordered tests was significantly higher in centers that participated in DRIVE study, compared with the standards of everyday practice $(\mathrm{p}<0.001)$.

In our study we did not use a survey for the patients, that would help us screen for the risk of infection; we did not focus our study on patients, but the number of laboratory tests. Maybe development and regular use of similar surveys for patients would make doctors' diagnostic decisions easier, also in Poland. Also training becomes an important element impacting making the decision to test, as it shows the specialists from different fields a broad spectrum of clinical symptoms suggesting chronic HIV infection.

A multicenter study called HIDES (performed in 2009-2011) aimed at identification of diseases and conditions pointing to the possibility of HIV infection and determination whether the prevalence of these conditions differs in different European countries, divided into geographical regions (1). The study was performed in 12 primary care centers, 3 hospital wards and 8 centers with a hospital and outpatient clinics. Personnel working in those establishments were trained in the field of performing the test for HIV. Patients who came to a doctor and had at least one of the pathological conditions from the list pointing to infection, were included into the tested group. At the end of the study, coordinators and clinical personnel filled out a survey. The highest proportion from among 3588 recruited patients came from the Eastern Europe region (39\%). In this case as much as $97 \%$ declared heterosexual orientation, compared to $60 \%$ in other regions of Europe. Analysis of the prevalence of clinical conditions suggesting the need to test for HIV showed high variability in different regions of Europe. The highest number of tests was ordered by the specialists working with sexually transmitted diseases and hepatologists monitoring HBV and $\mathrm{HCV}$ infection. A positive test result was found in 66 patients, which signified a newly diagnosed HIV infection. General frequency of positive test results tów w wieku 18-60 lat z kilku ambulatoryjnych jednostek opieki podstawowej oraz ze szpitali w Madrycie, pośród których 51,2\% zadeklarowało w kwestionariuszu przynajmniej jedną odpowiedź potwierdzającą ryzyko zakażenia HIV. Projekt trwał przez cały rok 2014. Zidentyfikowano $22(0,4 \%)$ nowe zakażenia, ale $18 \%$ osób, którym potwierdzono dodatni wynik, nie miało świadomości zakażenia. Aż 40,9\% nowo wykrytych zakażeń spełniało kryteria „Late Presenters”. Wskaźniki określające zlecanie testu HIV wynosiły 29,6/100 tys. pacjentów w badaniu DRIVE, podczas gdy w rutynowej praktyce poza projektem wykonuje się ich zaledwie 3,1/100 tys. Potwierdza to korzyść z ustrukturyzowanego programu edukacyjnego pracowników medycznych. Liczba zleconych testów była znacząco wyższa w podmiotach, które uczestniczyły w badaniu DRIVE, w porównaniu ze standardami codziennej praktyki $(p<0,001)$.

W naszym badaniu nie używano kwestionariusza przeznaczonego dla pacjentów, który pomógłby wstępnie zidentyfikować ryzyko infekcji; pacjenci nie byli przedmiotem badania, lecz liczba wykonanych testów laboratoryjnych. Być może opracowanie i regularne używanie podobnych kwestionariuszy dla pacjentów ułatwiłoby lekarzom decyzje diagnostyczne również w Polsce. Ważnym elementem decyzyjnym staje się też szkolenie, które pokazuje specjalistom różnych dziedzin szerokie spektrum objawów klinicznych sugerujących przewlekłą infekcję HIV.

Celem wieloośrodkowego badania HIDES (20092011 rok) było zidentyfikowanie chorób i stanów wskazujących na możliwość zakażenia HIV oraz ustalenie czy częstość występowania tych stanów różni się w poszczególnych krajach Europy, w podziale na regiony geograficzne (1). Badanie przeprowadzono w 12 przychodniach, 3 oddziałach szpitalnych i 8 jednostkach składających się ze szpitala i poradni przyszpitalnej. W podmiotach przeprowadzono szkolenie lokalnego personelu w zakresie wykonywania testów w kierunku HIV. Do testowania włączano pacjentów zgłaszających się do lekarza, u których stwierdzano przynajmniej jeden ze stanów chorobowych z listy wskazującej na zakażenie. Koordynatorzy i personel kliniczny na zakończenie wypełniali kwestionariusz. Największy odsetek spośród 3588 zrekrutowanych pacjentów dotyczył regionu Europy Środkowo-Wschodniej (39\%). Tutaj aż 97\% osób zadeklarowało orientację heteroseksualną, w porównaniu z $60 \% \mathrm{w}$ innych regionach Europy. Analiza częstości stanów klinicznych sugerujących potrzebę testowania HIV pokazała duże zróżnicowanie w różnych regionach Europy. Najwięcej testów zlecali specjaliści zajmujący się chorobami przenoszonymi drogą płciową oraz hepatolodzy monitorujący infekcję HBV i HCV. Dodatni wynik testu stwierdzono u 66 osób, co było równoznaczne z nowo rozpoznanym zakażeniem HIV. Ogólna częstość występowania dodatnich wyni- 
in all the participating countries was $1.8 \%(95 \% \mathrm{CI}$ : $1.42-2.34$ ). The highest number of positive HIV results in the HIDES study was demonstrated in the Southern Europe, where this ratio exceeded 5\%.

In the Polish "STOP Late Presenters" study, performed in four multi-specialist hospitals, among 459 tests, there were $0.87 \%$ positive confirmed cases. We cannot compare these results to HIDES results, because the prevalence of HIV in different regions of Europe is diversified and undergoes constant changes in the recent years. Moreover, in the Mazovian study, tests were not performed as a screening in all clinical cases suggesting the possibility of HIV infection. There were few tests ordered from neurology, intensive care, cardiology, ophthalmology, surgery, and other hospital wards. Most tests performed in hospitals were ordered in infectious disease and ob-gyn wards. This fact may be explained by higher sensitivity of doctors specialized in infectious diseases towards HIV/ AIDS, as they learn about this infection during their specialty training, while gynecologists are obliged to test pregnant women, according to the regulation of the Minister of Health dated 2012 and pertaining to prenatal care. In the document: Regulation of the Minister of Health dated September 20, 2012, on standards of medical management while rendering medical services concerning perinatal care for a woman during the time of physiological pregnancy, physiological birth, puerperium and care for the newborn child, there are stipulations on recommended scope of prophylactical tests and medical consultations, performed in women during the time of pregnancy, along with time periods of their performance (Government Regulations and Laws Gazette dated October 4, 2012, clause 1100, II). Moreover, Polish Scientific Society for AIDS systematically updates recommendations on HIV testing in pregnant women (9).

HIV testing, as a weak link of diagnostic algorithms, was analyzed in the countries with high HIV/AIDS incidence, like Nigeria (10). Results of the implemented improvement programs in the scope of early detection of HIV infection were analyzed. Organizers performed a weekly training on early detection of the infection and evaluation of serologic status of HIV among medical staff. Then, audits were run in hospital wards and based on them, diagnosis of early infection before and after the training was evaluated. From the general number of 5759 hospitalized patients, HIV testing was done in less than half $(42,6 \%)$. Still, this was four times more than before the training $(16 \%)$, and the difference was statistically significant.

In four Mazovian hospitals, average ratio of ordered HIV tests was $2.44 \%$ in respect to declared total number of hospitalized patients $(\mathrm{N}=112928)$. ków testu we wszystkich uczestniczących krajach wynosiła 1,8\% (95\% CI: 1,42 - 2,34). Największą liczbę dodatnich wyników HIV w badaniu HIDES uzyskano w Europie Południowej, gdzie odsetek ten przekroczył $5 \%$.

W polskim badaniu „STOP Late Presenters” w czterech szpitalach wielospecjalistycznych, na 459 wykonanych testów dodatni wynik testu potwierdzono w $0,87 \%$ przypadków. Nie można tych wyników odnieść do wyników HIDES, ponieważ prewalencja HIV w różnych regionach Europy jest zróżnicowana i ulega ustawicznym zmianom w ostatnich latach. Ponadto, w badaniu na Mazowszu testów nie wykonywano jako screening we wszystkich przypadkach klinicznych sugerujących możliwość infekcji HIV. Mało skierowań na test pochodziło z oddziałów neurologicznych, intensywnej terapii, kardiologii, okulistyki, chirurgii i innych oddziałów szpitalnych. Większość wykonywanych w szpitalach testów pochodzi z oddziałów i poradni chorób zakaźnych i ginekologiczno- położniczych. Fakt ten można wythumaczyć większym wyczuleniem na HIV/AIDS lekarzy specjalistów chorób zakaźnych, którzy tę infekcję poznają dokładnie podczas kształcenia specjalizacyjnego, zaś ginekolodzy mają obowiązek testowania kobiet w ciąży, zgodnie z rozporządzeniem ministra zdrowia z roku 2012 nt. opieki perinatalnej. W Rozporządzeniu Ministra Zdrowia z dnia 20 września 2012 r. w sprawie standardów postępowania medycznego przy udzielaniu świadczeń zdrowotnych z zakresu opieki okołoporodowej sprawowanej nad kobietą w okresie fizjologicznej ciąży, fizjologicznego porodu, połogu oraz opieki nad noworodkiem - istnieją zapisy na temat zalecanego zakresu świadczeń profilaktycznych i działań w zakresie promocji zdrowia oraz badań diagnostycznych i konsultacji medycznych, wykonywanych u kobiet w okresie ciąży, wraz z okresami ich przeprowadzania (Dz.U. 2012 poz. 1100). Ponadto Polskie Towarzystwo Naukowe AIDS systematycznie aktualizuje rekomendacje na temat testowania HIV u kobiet w ciąży (9).

Testowanie w kierunku HIV jako słabe ogniwo algorytmów diagnostycznych, analizowano w kraju o wysokim wskaźniku zapadalności na HIV/AIDS - Nigerii (10). Oceniano rezultaty wdrożonego programu poprawy w zakresie wczesnego wykrywania infekcji HIV. Wśród pracowników medycznych przeprowadzono tygodniowy kurs instruktażowy na temat wczesnego rozpoznawania zakażenia i oceny wyników statusu serologicznego HIV. Następnie przeprowadzono audyty w oddziałach szpitalnych i na ich podstawie oceniano diagnozowanie wczesnego zakażenia przed i po szkoleniu. Z ogólnej liczby 5759 hospitalizowanych chorych, test HIV wykonano u mniej niż połowy $(42,6 \%)$. Było to i tak czterokrotnie więcej, niż w okresie przed wdrożeniem badania (16\%), a różnica była istotna statystycznie. 
Significant increase of the number of ordered tests after education of medical personnel was noted also in a New York study in 2015 (11). First, electronic medical records were evaluated, and tests performed in emergency ward were selected. Because of low testing indices in this ward, investigators performed an intervention in the form of education and implementation of a course of action, according to a specific algorithm in patients from high risk groups for HIV infection. In this population the number of tests increased after intervention from $6.7 \%$ to $41.4 \%$ among patients admitted to the emergency ward.

In 2012-2015 investigators from Switzerland compared execution of national recommendations on HIV testing with everyday practice in two university hospitals in Lausanne (12). The study was motivated by the phenomenon of late HIV diagnosis among the Swiss patients. Among all 147884 hospitalized patients, HIV test was performed in 9653 patients, i.e. in $6.5 \%$ patients, and in 34 patients HIV infection was detected for the first time, which was $0.35 \%$ of all tested people.

In the hospitals included into our study, HIV testing was performed in only $2.44 \%$ of those hospitalized, and positive result was confirmed in $0.87 \%$ of all tested, i.e. in a ratio more than twice higher than among patients hospitalized in Lausanne. The Swiss study, just like the one performed in four Mazovian hospitals, included analysis of different specialists and specificity of hospital wards ordering HIV tests. After the training, the highest number of tests was ordered by the specialists in oncology, with significant increase from $12 \%$ in 2012 , to $16 \%$ in 2013 ( $\mathrm{p}=0.0005)$. The importance of education for the elevation of testing indices was also noted in neurology, internal medicine and psychiatry. It was surprising to see low numbers of tests coming from dermatology and surgery, even if patients coming to surgeons did not have clear symptoms suggesting HIV/AIDS risk, described in the national recommendations. Similarly to our study, a small number to HIV tests was ordered by cardiologists. The authors of the Swiss study noted that the improvement of HIV testing indices occurred as an effect of introduction of the national recommendations which list indications for the testing in specific clinical conditions. In Switzerland, these recommendations were employed in most multi-specialist hospitals and they are supervised by the Federal Departments of Health. Investigators stress that significant increase of the interest in HIV testing was the result of two things: national HIV/AIDS program and training of doctors, nurses, and diagnosticians. In Poland, there is a yearly updated document Recommendations of the Polish Scientific Society for AIDS, that should be used as instructions concerning diagnostic
W czterech mazowieckich szpitalach, średni odsetek zlecanych testów HIV wynosił $2,44 \%$ w stosunku do zadeklarowanej ogólnej liczny hospitalizowanych $(\mathrm{N}=112$ 928).

Znamienny wzrost liczby zlecanych testów po edukacji personelu odnotowano również $\mathrm{w}$ nowojorskim badaniu w roku 2015 (11). Na wstępie oceniano elektroniczną dokumentację medyczną, z której selekcjonowano wykonane testy HIV w oddziale ratunkowym. Z powodu niskich wskaźników testowania w tym oddziale dokonano interwencji w postaci edukacji i wdrożenia postępowania według określonego algorytmu u pacjentów w grupach wysokiego ryzyka zakażenia HIV. W tej populacji liczba testów zwiększyła się po interwencji z $6,7 \%$ do $41,4 \%$ wśród chorych przyjmowanych do oddziału ratunkowego.

Z kolei badacze ze Szwajcarii, w latach 2012-2015, porównywali wykonywanie krajowych rekomendacji na temat testowania HIV z codzienną praktyką, w dwóch szpitalach uniwersyteckich w Lozannie (12). Motywem badania było zjawisko późnej diagnozy HIV wśród szwajcarskich pacjentów. Spośród wszystkich 147884 hospitalizowanych test HIV został wykonany u 9653 osób, tj. u 6,5\% chorych, a u 34 osób wykryto po raz pierwszy zakażenia HIV, co stanowiło $0,35 \%$ wszystkich testowanych.

W szpitalach włączonych do naszego badania test HIV miało wykonane zaledwie $2,44 \%$ hospitalizowanych, w tym dodatni wynik potwierdzono u $0,87 \%$ wszystkich testowanych, tj. w odsetku ponad dwukrotnie wyższym niż wśród chorych hospitalizowanych w Lozannie. Szwajcarskie badanie, podobnie jak to przeprowadzone w czterech mazowieckich szpitalach, odnosiło się to analizy różnorodnych specjalistów i specyfiki oddziałów szpitalnych zlecających testy HIV. Po szkoleniu, najwięcej testów zlecali specjaliści w dziedzinie onkologii, gdzie nastąpił znaczący wzrost z 12\% w 2012 roku, do 16\% w 2013 roku ( $\mathrm{p}=0,0005$ ). Znaczenie edukacji dla podniesienia wskaźników testowania zauważono ponadto $\mathrm{w}$ oddziałach neurologii, interny i psychiatrii. Niespodzianką były niskie liczby testów pochodzące z oddziału dermatologii i chirurgii, chociaż pacjenci zgłaszający się do chirurgów nie mieli oczywistych objawów sugerujących ryzyko HIV/AIDS opisane w rekomendacjach krajowych. Podobnie jak w naszym badaniu, mało testów HIV zlecali kardiolodzy. Autorzy szwajcarskiego badania zauważają, że poprawa wskaźników testowania HIV nastąpiła pod wpływem wprowadzenia w życie krajowych rekomendacji, które opisują wskazania do wykonania testu w określonych stanach klinicznych. W Szwajcarii rekomendacje te zastosowano $\mathrm{w}$ większości szpitali wielospecjalistycznych i są one nadzorowane przez Federalne Departamenty Zdrowia. Badacze podkreślają, że dwa elementy wpłynęły na wzrost zainteresowania testowaniem HIV: 
proceeding when HIV infection is suspected (9). However, these recommendations are not popular among other specialists and are not implemented in healthcare institutions in Poland. On top of that, their implementation is not supervised by authorities responsible for the healthcare system in our country.

\section{SUMMARY AND CONCLUSIONS}

HIV testing should be an important element of healthcare policy and public health policy. Execution of tests for HIV in patients hospitalized based on conditions pointing to the possibility of infection, is the most effective strategy for the fight with HIV epidemic. Reduction of the number of non-diagnosed cases and earlier diagnosis of the infection are important elements of this fight, improving antiviral treatment costs, reducing long-term effects of AIDS and, most importantly, limiting viral transmission in the environment. ECDC recommendations say that people coming to any healthcare institution with any of the eight clinical conditions suggesting HIV infection should be obligatorily tested for HIV (2). Many planned observational studies in Europe confirm effectiveness of this strategy.

Study of the frequency of HIV tests performed in four multi-specialist hospitals in the Mazowieckie voivodeship, presented in this paper, is the first Polish attempt to evaluate the actual situation in the scope of HIV diagnosis and is a part of nationwide activities within "STOP Late Presenters" project. Against the background of other European countries, Poland shows low testing indices calculated for hospitals and specialist centers. In our study, HIV testing was performed in only $2.44 \%$ of hospitalized patients. In many hospital wards and specialist centers chronic HIV infection is not suspected as the cause of symptoms, with which the patient presents in specialist centers. We would like to cautiously stress the optimistic trend of higher interest of specialists in this topic and increase of the number of ordered tests in some wards, after the intervention in the form of training, leaflets and instruction on testing. Wrongly, doctors are convinced that HIV and AIDS lay in the field of interest of only infectious disease specialists. Patients with symptoms of HIV infection may be admitted to any hospital ward, admission room, emergency room and any specialist center. Actual practice for HIV testing is inconsistent in wards of the same specialty and differ between individual hospitals. Existing documents and guidelines of the Polish Scientific Society for AIDS and accepted by the Minister of Health and National Health Fund form a very strong theoretical base for the implementation of local diagnostic algorithms for everyday practice. narodowy program HIV/AIDS oraz szkolenie lekarzy, pielęgniarek i laborantów.

W Polsce istnieje aktualizowany co roku dokument pt. Zalecenia Polskiego Towarzystwa Naukowego AIDS, który powinien stanowić instrukcję w postępowaniu diagnostycznym przy podejrzeniu zakażenia HIV (9). Jednakże zalecenia te są mało znane innym specjalistom i nie są implementowane w podmiotach leczniczych w Polsce, ani ich wykonanie nie jest nadzorowane przez organy odpowiedzialne za opiekę zdrowotną w naszym kraju.

\section{PODSUMOWANIE I WNIOSKI}

Testowanie HIV powinno być ważnym elementem polityki zdrowotnej i zdrowia publicznego. Wykonywanie testów w kierunku HIV u pacjentów hospitalizowanych na podstawie stanów wskazujących na możliwość zakażenia jest najbardziej skuteczną strategią walki z epidemią HIV. Istotnym elementem w tej walce jest redukcja liczby niezdiagnozowanych przypadków oraz wcześniejsze rozpoznanie infekcji, co poprawia efekty leczenia przeciwwirusowego, zmniejsza skutki odległe choroby AIDS i przede wszystkim ogranicza transmisję wirusa w środowisku. Zalecenia ECDC nakazują, aby osobom, które zgłaszają się do jakiegokolwiek podmiotu leczniczego z którymś z ośmiu stanów klinicznych wskazujących na infekcję HIV, bezwzględnie wykonywać test w kierunku HIV (2). Wiele zaplanowanych badań obserwacyjnych w Europie potwierdza skuteczność tej strategii. Przedstawione w niniejszym doniesieniu badanie częstości wykonywanych testów HIV w czterech wielospecjalistycznych szpitalach Mazowsza, jest pierwszą w Polsce próbą oceny realnej sytuacji diagnozowania HIV oraz jest częścią ogólnopolskich działań w ramach projektu „STOP Late Presenters”. Na tle innych krajów europejskich, Polska wykazuje niskie wskaźniki testowania w warunkach szpitalnych i poradniach o różnorodnej specyfice. W naszym badaniu zaledwie 2,44\% pacjentów hospitalizowanych miało wykonany test w kierunku HIV. W wielu oddziałach szpitalnych i poradniach nie podejrzewa się przewlekłej infekcji HIV jako przyczyny symptomów, z którymi pacjent się zgłasza do gabinetów specjalistycznych. Ostrożnie należy podkreślić optymistyczny trend, że po interwencji w postaci szkolenia, ulotek i instruktażu o testowaniu, zwiększyło się zainteresowanie specjalistów tym zagadnieniem i w niektórych oddziałach liczba zleconych testów wzrosła. Niesłusznie panuje przekonanie, że HIV i AIDS to obszar zainteresowań tylko lekarza chorób zakaźnych. Pacjent z objawami infekcji HIV może się znaleźć w każdym oddziale szpitalnym, w izbie przyjęć, w oddziale ratunkowym i każdej przychodni specjalistycznej. Realne praktyki testowania HIV są niejednolite w obrębie oddziałów o tej samej 
Statistical analysis of raw data, preparation of figures and tables was done by HTA Consulting, while the whole project was created with organizational and theoretical support by GILEAD Sciences Poland Sp. $z$ o. o., within the frames of "STOP Late Presenters" project and regional consultant for infectious diseases in the Mazovia region.

\section{REFERENCES}

1. Sullivan AK, Raben D, Reekie J, et al. Feasibility and Effectiveness of Indicator Condition - Guided Testing for HIV: Results from HIDES (HIV Indicator Diseases across Europe Study). PLoS One 2013; 8 (1): e52845 doi:10.1371/journal. pone. 0052845

2. European Centre for Diseases Prevention and Control. HIV/AIDS surveillance in Europe 20182019. Available at: https://www.ecdc.europa.eu/ en/publications-data/hivaids-surveillance-europe2019-2018-data

3. Girardi E, Sabin GA, Monforte AD. Late diagnosis of HIV infection: epidemiological features, consequences and strategies to encourage earlier testing. J Aquir Immune Defic Syndr. 2007 suppl 46; 1:S3-S8.

4. Bander D, Leszczyszyn-Pynka M, BorońKaczmarska A. Late AIDS diagnosis inpatients hospitalised in Clinic of Infectious Diseases and Hepatology PAM in years 2003-2007. Przegl Epidemiol 2009; 64(1):61-65

5. Public health guidance on HIV, hepatitis B and C testing in the EU/EEA - An integrated approach. Stockholm: ECDC; 2018. Available at: https:// www.ecdc.europa.eu/en/publications-data/publichealth-guidance-hiv-hepatitis-b-and-c-testingeueea

6. Walensky RP, Freedberg KA, Weinstein MC, et al. Cost-effectiveness of HIV testing and treatment in the United States. Clin Infect Dis 2007; 45:248254.

7. Joore IK, Arts DL, Kruijer MJ, et al. HIV indicator condition-guided testing to reduce the number of undiagnosed patients and prevent late presentation in a high-prevalence area: a case-control study in primary care. Sex Trans Infect 2015; 91:467-72.

8. Gomez-Ayerbe C, Martinez-Sanz J, Muriel A, et al. Impact of a structured HIV testing program in a hospital emergency department and primary care center. PLoS One 2019;1: 1-7. specyfice i różnią się także pomiędzy poszczególnymi szpitalami. Istniejące opracowania i wytyczne wyznaczone przez Polskie Towarzystwo Naukowe AIDS i zaakceptowane przez Ministra Zdrowia oraz Narodowy Fundusz Zdrowia, stanowią bardzo mocną podstawę teoretyczną do wprowadzania lokalnych algorytmów diagnostycznych do codziennej praktyki.

Opracowanie statystyczne wyników surowych, wykonanie wykresów i tabel zlecono firmie HTA Consulting, a caly projekt powstat przy wsparciu organizacyjnym i merytorycznym GILEAD Sciences Poland Sp. z o. o. w ramach projektu „STOP Late Presenters” oraz konsultanta wojewódzkiego $w$ dziedzinie chorób zakaźnych dla Mazowsza.

9. Zalecenia zapobiegania transmisji wertykalnej HIV. w: Zasady opieki nad osobami zakażonymi HIV. Zalecenia PTN AIDS. Warszawa 2019: 112116.

10.Seconi OO, Aderibigbe SA, Acande TM. Effect of health education on willingness to undergo HIV screening among Antenatal Attendees in a Teaching hospital in North Central Nigeria. BioMed Reasearch International 2016; 1:1-5.

11.Felsen UR, Bellin EY, Cunningham CO, Zingman BS. Development of an electronic medical recordbased algorithm to identify patients with unknown HIV status. AIDS Care 2014; 26(10):1318-1325

12.Darling KE, Hachfeld A, Cavassani M, et al. Late presentation to HIV care despite good access to health services: current epidemiological trends and how to do better. Swiss Med Wkly 2016; 146:11-16.

Received: 19.12.2019

Accepted for publication:10.03.2020

Otrzymano: 19.12.2019 r.

Zaakceptowano do publikacji: $10.03 .2020 \mathrm{r}$.

Adres do korespondencji:

Address for correspondence:

Grażyna Cholewińska

Wojewódzki Szpital Zakaźny w Warszawie

01-201 Warszawa, ul. Wolska 37.

e-mail: cholegra@zakazny.pl

tel. 223355205 